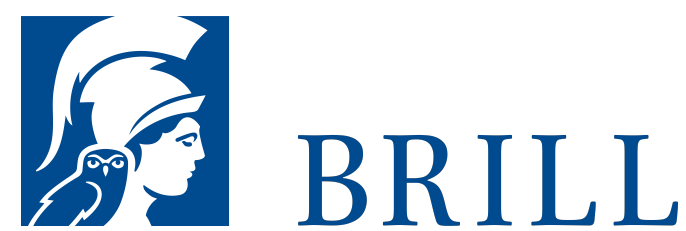

\title{
Emotions as Natural and Social Kinds
}

\section{An Integrative Approach To Evolutionary And Social}

Constructionist Perspectives On Emotions

Author: Anna Welpinghus

Emotions are shaped by evolution and they are shaped by culture. This book explores several ways in which emotions are shaped by culture, and examines what they tells us about the nature of emotions. A crude dichotomy between evolution and culture is certainly not warranted, since evolutionary frameworks can accommodate many cultural influences on emotions. However, the most deeply culturally shaped emotions, those which deserve to be called 'socially constructed', call for significant modifications of existing evolutionary frameworks. This book argues for a new version of Social Constructionism for emotions: Some emotions are social kinds rather than non-social natural kinds. This study thereby introduces new distinctions apart from the familiar distinction between cognitive and non-cognitive emotions. This book includes some applications to topics of practical relevance: jealousy is neither a paradigmatic cognitive emotion nor a paradigmatic basic one. This analysis casts doubt on the cognitive/basic distinction and speaks against an overtly moralized understanding of jealousy. Finally, some arguments about the desirability of exclusivity in romantic relationships are explored.

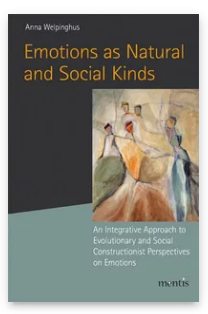

Pages: 205

Seiten

Language:

English

Subjects:

General,

Philosophy

Publisher: Brill | mentis

E-Book (PDF)

Released online: 21 Apr 2015

ISBN: $978-3-$

95743-921-5

List price

Paperback

Publication date:

21 Apr 2015

ISBN: 978-3-

95743-004-5

List price 
For more information see brill.com

Order information: Order online at brill.com +44330 333 0049 | customerservices@brill.com Submission information: brill.com/authors

Titles published by Brill | Fink, Brill | mentis or Brill | Schöningh: +49(o)715413279216| brill@brocom.de 